Article

\title{
Sexualization of Female Perpetration in Fictional Holocaust Films: A Case Study of The Reader (2008)
}

\author{
Sabine Elisabeth Aretz \\ Department of English, American and Celtic Studies, University of Bonn, 53113 Bonn, Germany; \\ sabine.aretz@uni-bonn.de
}

Received: 10 August 2019; Accepted: 26 September 2019; Published: 28 September 2019

\begin{abstract}
The publication of Bernhard Schlink's novel The Reader (1995) sparked conversation and controversy about sexuality, female perpetrators and the complexity of guilt regarding the Holocaust. The screen adaptation of the book (Daldry 2008) amplified these discussions on an international scale. Fictional Holocaust films have a history of being met with skepticism or even reject on the one hand and great acclaim on the other hand. As this paper will outline, the focus has often been on male perpetrators and female victims. The portrayal of female perpetration reveals dichotomous stereotypes, often neglecting the complexity of the subject matter. This paper focuses on the ways in which sexualization is used specifically to portray female perpetrators in The Reader, as a fictional Holocaust film. An assessment of Hanna's relationship to Michael and her autonomous sexuality and her later inferior, victimized portrayal as an ambiguous perpetrator is the focus of my paper. Hanna's sexuality is structurally separated from her role as a perpetrator. Hanna's perpetration is, through the dichotomous motif of sexuality throughout the film, characterized by a feminization. However, this feminization entails a relativization of Hanna's culpability, revealing a pejorative of her depiction as a perpetrator. Consequently, I argue that Hanna's sexualized female body is constructed as a central part of the revelation of her perpetration.
\end{abstract}

Keywords: The Reader; Holocaust film; sexualization; sexual objectification; female perpetration; Holocaust iconography; Nazisploitation; Male Gaze

\section{Introduction}

Stephan Daldry's film adaptation of The Reader (2008) has been called a "Holocaust-Sex-Film" (Sander 2009) or "Nazi Porn" (Shipman 2009). Other film critics have accused such delineations to have misunderstood the film due to their own voyeuristic gaze at Kate Winslet's naked body (Relke 2011, p. 378). These provocative remarks reflect some of the discussion about the theme of sexuality in Holocaust movies that the release of The Reader has sparked. Pitted against these discussions are reviews that interpret The Reader as a love story and identify "passion" and "the immorality of love" as the film's themes (Schulz-Ojala 2009). Although the particular tension that the theme of sexuality in combination with fictional reprocessing of the Holocaust might appear self-evident, it is noteworthy how The Reader sparks both outrage for sexualizing or fetishizing a (fictional) Holocaust perpetrator by some while also being enjoyed as a romantic drama by others.

The Reader is based on Bernard Schlink's novel (1995) and, through the perspective of Michael Berg [David Kross], tells the story of an affair between the 15-year-old Michael and the 36-year-old former concentration camp supervisor Hanna Schmitz [Kate Winslet]. After the affair abruptly ends, Michael sees Hanna again when he attends a trial as a law student. As a former concentration camp supervisor, Hanna is on trial for murder in 300 cases and eventually sentenced to prison.

The film's depiction of a female perpetrator's sexual relationship, whose perpetration and culpability are ambiguous, allows for an investigation into the sexualization of female perpetration 
in fictional Holocaust films, specifically popular cinema. While fictionalizations of the Holocaust contributed to the cultural memory and potential reprocessing, Holocaust stories depicted in popular culture in particular are at risk of sacrificing complex discussions of the unsettling reality of the Holocaust in order to provide a broadly appealing narrative.

Sexualization in depictions of the Holocaust, as this paper will discuss, stands in direct relation to the portrayal and perception of the perpetrator's complexity and culpability, therefore functioning as a way to either dismiss the perpetrator's humanity or to relativize their liability. This is particularly evident in the depictions of female perpetrators. I will first discuss how the rhetoric of sexualization, sexual objectification, and feminization can be cinematically conveyed. An analysis of sexualization, the depiction of women and specifically the depiction of female perpetrators in fictional Holocaust films will then offer a framework in order to understand the function of sexualization in The Reader.

A number of scholarly works have addressed and analyzed both the historical role of female perpetrators in the Holocaust as well as the fictionalizations of the Holocaust with regard to female perpetration and sexualizations. Section 3 will outline the key arguments. This paper expands on these by providing a detailed analysis of The Reader as a case study revealing the implications of sexualization in the fictional depiction of female perpetration. A detailed analysis of The Reader will reveal the dichotomous portrayal of Hanna, who embodies a sexual, dominant woman on the one hand and an inferior, conflicted culprit, whose portrayal sometimes blurs the lines of victim and perpetrator, on the other hand. This dichotomy is crucial in order to examine the interplay of the depiction of Hanna's sexuality and her role as a perpetrator. While Hanna's sexuality is structurally separated from the reveal and problematization of her ambiguous perpetration, Hanna is ultimately characterized by a specific undermining feminization, carried by the film's narrative perspective. Because this is decisive in the decrement of Hanna's perpetration that the film conveys, I argue that Hanna's sexualized female body is constructed as a central part of the revelation of her perpetration.

\section{2. (Rhetoric of) Sexualization and Sexual Objectification}

Sexualization, in general, describes the inappropriate foregrounding or imposing of a person's sexuality and sexual appeal. Beyond emphasizing a person's sexuality, sexualization hence can also refer to the act of relating something or someone to a certain sexuality without them presenting their sexuality in any sense (Zurbriggen et al. 2007). This definition reveals the existence of a sexualizing subject and a sexualized object, which largely describes a hierarchical dynamic, whereby the sexualization is initiated by the active subject. Additionally, the sexualized person's lack of agency is crucial to the concept of sexualization, notably separating it from self-motivated or self-empowered displays of (healthy) sexuality and sexual desire (Zurbriggen et al. 2007).

This becomes particularly evident in the definition of sexual objectification. Objectification theory (Fredrickson and Roberts 1997) has played a significant role in the scholarly discussion of the female experience. In general, objectification describes the act of putting someone in a position that allows a consideration of them as an object, ridding them of value as an equal (Nussbaum 1995). Sexual objectification is thus defined as the act of regarding someone as "a thing for others" sexual use, rather than see[ing them] as a person with the capacity for independent action and decision making." (Zurbriggen et al. 2007, p. 1). Therefore, the act of sexual objectification entails the portrayal of people as "dehumanized ... sexual objects, things, or commodities" (MacKinnon 1987, p. 176). The topic of sexual objectification has received notable attention from feminist scholars, arguing that the (sexual) objectification of women is a crucial component to preserve the power dynamics in a patriarchal society (Connell 1987; Kuhn 1985). The acts of sexualization or sexual objectification, particularly in pornography, reveal the loss of the sexualized or sexually objectified person's autonomy, power, moral standing and humanity (LeMoncheck 1985; Haslam et al. 2013). Consequently, sexualization and sexual objectification can function as components of dehumanization, which furthers a person's loss of agency. 
Most research regarding sexualization focuses on the sexual objectification of women, which is argued to have a profound impact on social power dynamics as well as women's self-perception. Social ideals and ideas of femininity are therefore connected to the social process of sexual objectification. With sexual objectification being defined as "a woman's body or body parts [being] singled out and separated from her as a person, [viewing her] primarily as a physical object of male sexual desire" (Szymanski et al. 2011, p. 7), the female body is rendered as inferior and obedient to male desire. Femininity, as a social construct, consequently, communicates this social hierarchy. Especially when tied to sexualization or sexual objectification, the process of feminization hence entails the communication of a clear power dynamic, in which femininity functions to imply inferior characteristics. The function of feminization largely depends on the underlining power dynamic and the particular social construct of femininity. In a patriarchy that uses sexualization and sexual objectification to communicate the inferiority of women, however, imposed feminization, carrying signifiers of weakness and subordination, functions as a tool of female disempowerment (Wenk 2002).

Women in classical Hollywood cinema are, according to Laura Mulvey, reduced to their status as erotic objects by films through a, narratively and technically, male perspective (Vandermassen 2010). "The Male Gaze," as coined by Mulvey (1985), describes the relationship between women as "to-be-looked-at ... passive objects for male fetishistic gazing and desire" and men as "active agents and as possessors of the gaze, and hence, as representatives of power" (Vandermassen 2010, p. 69). Mulvey argues that masculinity is used as the narrative perspective in classical Hollywood cinema and, adapting a psychoanalytical concept that is based on Sigmund Freud's theory of sexuality for film, describes the Male Gaze as rhetoric for cinematic sexualization. Moreover, Mulvey views the concept as a reflection of the unequal power relation between men and women:

In a world ordered by sexual imbalance, pleasure in looking has been split between active/male and passive/female. The determining male gaze projects its phantasy on the female figure which is styled accordingly. In their traditional exhibitionist role women are simultaneously looked at and displayed, with their appearance coded for strong visual and erotic impact ... (Mulvey 1985, p. 808)

The projection of the male fantasy, which is created through the act of gazing, ultimately defines the Male Gaze. The female body is accordingly variable, defined by and dependent on its observer. Therefore it becomes evident that the aspect of control and consequently the exercise of power of the observer towards the observed plays a crucial role and the Male Gaze is defined through its controlling, subject-oriented nature (Mulvey 1985; Vandermassen 2010). Consequently, a cinematic perspective that could be described as a Male Gaze presents the cinematic realization of the establishing and reassuring of clear power dynamics that sexualization and sexual objectification carry.

While this is perhaps most obvious in pornography (LeMoncheck 1985), the visual exploitation of a sexualized female body by a male perspective is not unique to pornography (Erens 1990; Heldman et al. 2016). In this process, the appearance of a woman is construed to be a primarily visual, erotic depiction, " ... so that [women] can be said to connote to-be-looked-at-ness" (Mulvey 1985, p. 809). The passive role of women thus contains the emergence as an unreluctant object that is putting itself on display and thereby inviting the Male Gaze.

\section{Sexualization in Holocaust Films}

In the analysis of the remembrance of female perpetrators in the Holocaust, it is relevant to note that, although the collective remembering of the Holocaust largely focuses on male perpetrators, women were directly and indirectly involved as perpetrators (Sarti 2011). Historical findings on the role of women as perpetrators in the Holocaust reveal that despite the patriarchal, misogynist order and ideology of Nazi Germany, women directly participated in the Holocaust as perpetrators in various roles, exceeding the role of the bystander or silent emotional enabler of powerful male perpetrators (Herkommer 2008). Further, multiple scholarly works have extensively demonstrated 
the cruelty used by female perpetrators in their role as concentration camp guards, supervisors or in the domestic sphere, arguing that female perpetration in the Holocaust is not limited to willful ignorance or passive support (Brown 2011; Heike 2008; Herkommer 2008). A historical analysis of the evaluation of female perpetrators in post-war trials suggests a frequent feminization or sexualization of female perpetration (Herkommer 2008). In this regard, a demonization of the perpetrator is argued to ultimately extenuate the perpetrator's responsibility (Duesterberg 2002). Moreover, these historical accounts are indicative of a deep-rooted cultural discomfort in addressing the complexities of female perpetration. Female perpetration has often been entirely neglected or framed as trivial in fictional and non-fictional discussions, portrayals and recollections of the Holocaust. This portends to a patriarchal nature in the approach to female perpetration (Mushaben 2004). This chapter will provide an overview of the depiction of women and female perpetrators in fictional Holocaust films.

\subsection{Depiction of Women}

Fictional, particularly Hollywood, productions of Holocaust narratives have been criticized for simplifying, romanticizing and/or universalizing Holocaust events (Baron 2010; Doneson 1987; Langer 1995). Regarding the portrayal of women in these films, Anna Reading notes that "universalisation includes the stripping away of the rich variety of gendered roles and experiences and the use instead of gendered stereotypes, framed within the particular conventions of-in many cases-American masculinity and femininity current at the time of the film's production" (Reading 2002, p. 95).

Most depictions of women in Holocaust films predominantly reveal a marginalization (Fuchs 1999; Waterhouse-Watson and Brown 2016). Waterhouse-Watson and Brown (2014) argue that men function as key figures while the portrayal of women is more focused on an erotic aesthetic that supports the narrative thread of the male protagonists and also reflects the "intertwined nature of Nazism and patriarchy." In most cases, women are portrayed as passive, tragic victims defined by their relation to men as wives, lovers, or mothers (Fuchs 1999). Notably, many fictional Holocaust films also show female victims in the context of a (tragic) love story. Examples include Kapo (Pontecorvo 1960), Gold of Rome (Lizzani 1960), Enemies, A Love Story (Mazursky 1989), and Angry Harvest (Holland 1985). As Esther Fuchs outlines:

Romantic narratives in European Holocaust films tend to frame the Jewess as either femme fatale or the ultimate victim of erotic obsession. She lives for love, dies for love, and if she survives she survives thanks to love, which is sexual rather than platonic, marital, or familial. (Fuchs 2008, p. 287)

Furthermore, Fuchs (1999) asserts that women in Holocaust films behave primarily in a heightened emotional manner and/or are ignorant towards any political complexity. Fuchs as well as Waterhouse-Watson and Brown conclude that Holocaust films portray women as "sexualised and eroticised objects" (Waterhouse-Watson and Brown 2014) and "marginalized and stereotyped as sexual objects, or as emotional reflectors" (Fuchs 1999, p. 49). Many acclaimed Holocaust films, however, have been credited for depicting men's experiences and emotions in a more complex manner. Schindler's List (Spielberg 1993) and Life is Beautiful (Benigni 1997), for instance, reveal narrative threads in which the man's perspective functions at the core of the story in a way that results in a reduction of the portrayed women to passive, weaker and often more emotional one-dimensional characters. In Schindler's List, both the sexual violence by Amon Goeth, the brutal SS perpetrator, against Helen Hirsch, his beautiful Jewish housemaid, as well as the dynamic between the hero, Oskar Schindler, and the female victims he saves are discussed in this context (Fuchs 1999). The sexualization in these cases is defined by heteronomy, as there is no portrayal of autonomous female sexuality and instead women are sexualized through men's glances and actions. 


\subsection{Portrayal of Female Perpetrators}

Next to sometimes romanticized depictions of female victims (Fuchs 1999, 2008) stands an overt sexualization of female perpetrators with its concomitant rhetoric of pornographization (Wenk 2002). This rhetoric and the preceded sexualization are, however, not to be reduced to the genre of pornography but instead a part of several depictions of the Holocaust, including cinematic ones. Visualizations of the Holocaust, following Wenk (2002), make use of female bodies and their nudity in order to find justifications. Hence, the sexualization of the Holocaust and specifically its female perpetrators is paralleled with the motif of the seductive National Socialism, personified through the sexuality and the emphasis on the bodies of female perpetrator figures (Duesterberg 2002; Stiglegger 1999).

Women who participated in the National Socialist genocide contravene the characteristics that are stereotypically and institutionally associated with female behavior, consequently prompting their portrayal with a complex and problematic nature. Marianne Hirsch theorizes that visualizations of the Holocaust reveal an infantilized representation of mostly female victims and hyper-masculine perpetrators (Hirsch 2002). This also alludes to the observation that women are traditionally associated with the role of the victim. Due to the devastating character of Holocaust perpetration in general, an identification on behalf of the audience with the perpetrator is, in most Holocaust films, unlikely. Consequently, it stands to reason that the sexual objectification of female perpetrators functions as a dehumanization of the character and hence a way to avoid conceptualizing the perpetration and the cruelty of the deed.

First of all, it is to be noted that the term "perpetration" is not unequivocally defined. Claudia Nickel and Silke Segler-Meßner explain:

Obgleich der Täterbegriff auf den ersten Blick leicht zu definieren ist, beinhaltet er eine pauschalisierende Dimension, die zahlreiche Formen und Abstufungen von Täterschaft umfasst: vom Schreibtischtäter über den Mitläufer bis hin zum Vollstrecker der Handlung. ${ }^{1}$ (Nickel and Segler-Meßner 2013, p. 9)

The transition between the various stages and layers of perpetration is fluid and specific to each situation, person and circumstance (Von Wrochem 2013). As evident, a generalization needs to be avoided since it cannot universally be ruled out that a perpetrator is, in other dynamics or circumstances, a victim (Reemtsma 2007). Nevertheless, these considerations are highly sensible and, in fictional depictions of the Holocaust, might reveal to be largely discomforting for a mass audience. Hence, particularly popular Hollywood fictionalizations of the Holocaust might be assumed to shift towards more morally unambiguous portrayals with ultimately clear distributions of perpetration and guilt. In how far this applies to The Reader is part of the analysis of this paper.

The visualization of female perpetration is, contiguous to the ambivalent definition of perpetration in general, especially fractured. Based on the assessment that female perpetration is particularly difficult to conceptualize in a society that perpetuates "traditional notions of femininity as peaceful and innocent [which now] collide with images of women as war criminals" (Sjoberg 2013, pp. 230-31), three main strategies of the stereotyping of female National Socalist (NS)-perpetrators can be identified: a depiction of perpetration shaped by naiveté; female perpetrators as seduced objects; and the portrayal of the entirely dehumanized NS-beast (Duesterberg 2002). For instance, the latter can be found in the portrayal of Ilsa Koch in Ilsa, She Wolf of The SS (Edmonds 1975), Magall in La Bestia in Calore (Batzella 1977) and Ihamain in Eichmann (Young 2007). As Rapaport observes, "The Holocaust is not just being sexualized, but it is also being gendered-a woman in power is evil, a Nazi, a feminazi" (Rapaport 2003, p. 63). Aggressive, female sexuality is being depicted as parallel to and, ultimately, the cause of NS-crimes.

1 Translation: Although the term "perpetrator" seems to be easy to define at first glance, it encompasses a generalizing dimension that includes several forms and nuances of perpetration: from desk criminals to collaborators to executors. 
This demonstrates a lack of complexity in the depiction of women as they adopt the role of a perpetrator (Duesterberg 2002). Consequently, it illustrates the problematic nature of the portrayal of femininity in connection to perpetration. In this, a sexualization can already be assessed insofar that the mentioned stereotypes share the notion that women are not being regarded as autonomous subjects who can make their decisions independently or are capable of assessing the (im)morality and consequences of their actions (Duesterberg 2002). The object/subject relationship, which is the basis for sexualization, becomes evident. Lina Wertmüller's film Seven Beauties (1975) is a notable example in this context (Brown 2011).

In the case of the NS-beast, the portrayal of female perpetrators denies a complexity behind the perpetration. Further, an exploration into the reasoning, twisted self-evaluating, fallacious sense of morality or deeper motivation and dynamic behind the perpetration fade in the light of a heightened sexuality. The flaring linkage of Holocaust perpetration and female deviant sexuality ultimately explains the female perpetrator's behavior. Consequently, her sexuality is exploited as well as condemned (Duesterberg 2002). The phenomenon of Nazisploitation and, in the most extreme cases, Nazi pornography illustrate the apparent appeal of this portrayal. Nazisploitation, which found its golden age with a niche audience in the 1970s, is a subgenre of exploitation films, largely portraying hyper-sexualized fictional stories of Holocaust perpetrators (Magilow et al. 2012).

Sexualization in the depiction of perpetration shaped by naiveté and female perpetrators as seduced objects, to a certain extent, functions similarly. These depictions, like portrayals of the NS-beast, highlight the dehumanizing aspect of female perpetration that denies the perpetrator her criminal liability. Portrayals of female perpetrators in Holocaust films reveal a tendency to relativize the criminal liability of the perpetrator either through their immense naiveté; their dehumanized portrayal as pure monsters; or their subordinate, passive role as a seduced object, all of which deny the human complexity and capability of choice necessary to discuss and attribute culpability. Further examples of notable portrayals of female perpetrators in fictional Holocaust films include The Hiding Place (Collier 1975), Triumph of the Spirit (Young 1989), Playing for Time (Mann and Sargent 1980) and The Devil's Arithmetic (2004).

\section{Sexuality in The Reader}

Most discussions of The Reader address the salient theme of sexuality in both the book and the film adaptation. Analyzing Bernard Schlink's novel, Schlipphacke (2002), for instance, argues that The Reader partly portrays Hanna as a victim, which ultimately fails to deconstruct the conventional binary of male perpetrators and female victims. While being critical of The Reader's engagement with moral ambiguities, Donahue (2010) sees no link between Hanna's role as a sexual predator and her Holocaust perpetration. Ingrid Lewis (2017), however, argues that The Reader's eroticization of a female perpetrator is reflective of a cultural sensationalization of Nazism. Other interpretations point out the function of Hanna's seduction of Michael as a metaphor for the seductions of fascism, which, with its implications about gender, has been problematized (Metz 2004; Relke 2011).

The Reader primarily displays sexuality as a prominent motif through the relationship between Michael Berg and the former concentration camp supervisor Hanna Schmitz. This is particularly evident in the first half of the film, in which the story of the initially predominantly sexual relationship between Michael and Hanna is told. As evident here, the film is mainly introduced through the theme of sexuality, on the basis of which the narrative unfolds.

The motif of sexuality is introduced within the first ten minutes of the film through a scene in which Michael is being watched by Hanna while he is changing his clothes. At first, a point-of-view shot shows a close-up of Michael's expression [08:55], followed by a tight close-up shot of Hanna's leg, revealing what Michael's gaze was directed at [08:57-9:03]. Michael's embarrassed look as well as his decision to run away suggest that he has discovered Hanna as an "erotic object" (Donahue 2010, p. 164). This introductory scene establishes clear point-of-view shots that indicate the focus on Michael's 
perception of Hanna. The affair between Michael and Hanna that ensues is, however, clearly initiated by Hanna.

\subsection{Hanna's Relationship to Michael}

At the beginning of the film, the affair reveals a dominant and almost aggressive side of Hanna. The underlying age difference establishes Hanna's initial dominance over Michael. In the presence of Michael, Hanna presents herself as controlling and confident. This is particularly evident in their first physically intimate interaction [14:25-15:35], in which Hanna simply expects to have Michael's interest and consent and their sexual relationship starts. Because there is no clear sexual consent and Michael is under-aged, which already classifies this sexual encounter as inappropriate and immoral, Hanna is introduced not only through her sexual desire but through sexual deviance. While Hanna is not revealed as a Holocaust perpetrator at this point in the narrative, this characterization is crucial.

The same dynamic is prevalent in the first extended sex scene that, from Michael's perspective, has a didactic aspect to it [17:17-18:03]. Both lovers are presented in a medium shot in which Michael's face is in the foreground, at the center of the image, while Hanna's body can be seen in the bottom half of the shot. The scene is therefore focused on Michael's perspective. His experience and insecurity are highlighted. With that, Hanna's role as a sexual predator is, intradiegetically speaking, seemingly challenged as Michael's consent and pleasure are unquestionably evident at every moment. The depiction of Michael's memories of his sexual encounter with Hanna functions in the same sense as they reveal him in a dominant sexual role [15:50-15:52; 15:57-16:00]. Later, we see Hanna kiss Michael's bare upper body [29:20-29:33]. Again, Michael's pleasure and experience are the focus of these shots. As Donahue describes:

The Hanna as portrayed by Winslet is vulnerable, sensitive, and sometimes quite willing to submit herself (and not just because of her illiteracy) to her young lover-as we see when she scrubs every inch of his naked body prior to their final lovemaking scene. (Donahue 2010, p. 158)

Using the example of the scene Donahue mentions [40:21-41:32], a dichotomy of Hanna's character regarding her relationship with Michael becomes evident. While she takes care of him, she does so in an at times aggressive, perhaps even non-consensual manner. As Diana Relke observes, "[m]oments of alternating tension and tenderness characterize Hanna's initial seduction of Michael and the ensuing affair" (Relke 2011, p. 379).

Over the course of the relationship, Michael develops into a more determined figure against whom Hanna struggles [39:38]. A more complex distribution of power develops, which is carried by the imbalance between the two lovers and expressed in the prominent and defining theme of Michael reading to Hanna. The affair between Hanna and Michael mainly demonstrates gender disparity and Michael's privilege as a young man (Donahue 2010). Consequently, the arc of the first half of the film reveals Michael's power and therefore shifts the presentation of Hanna.

Despite her initial determined, dominant and secure manner, Hanna's femininity-in a traditional sense-is eventually uncovered and emphasized through her relationship to Michael. A stereotypical gender-specific distribution of power develops, revealing Hanna's subordination and dependency as a woman. Because Hanna is presented through Michael's perspective, she is continuously being portrayed as weaker while Michael's self-confidence develops and expands. Eventually, Hanna is completely dependent on Michael [01:30:23-01:31:17]. Notably, it is the shift in Hanna's portrayal from her dominant sexual deviancy to passive femininity that leads Hanna out of the role of a clear villain. This indicates that her sexuality and the conceptualization of her femininity stand in direct correlation to the evaluation of her role as a perpetrator, which is revealed in the second part of the narrative.

The evolution of the relationship between Hanna and Michael in the first half of the film causes the sexual relationship to gain a romantic layer through which Hanna's ability to love, presented through Michael's adoring, infatuated perspective, becomes clear. In this regard, she is notably humanized and 
her introduction as a morally flawed character at best and a downright sexual predator at worst is countered. A scene in which Hanna, during a bike tour with Michael, goes into a church and gets emotional while listening to a choir is exemplary of this re-characterization [32:58-33:37]. This scene is carried by Michael's observation of her. His emotions are in the foreground, functioning to add a tender side to Hanna. At this point in the narrative, she takes up the role of a lover. Therefore, when her role as a perpetrator is addressed, Hanna has already been presented through a sexualized lens, although her sexuality is notably autonomous and, at first, seemingly dominant, and a feminized perspective in which she takes on a weaker, passive role most clearly visualized when Michael is reading to her. Ultimately, Hanna and Michael's relationship is, in disregard of its problematic nature, established as a romantic relationship accompanied by a determining sexuality.

\subsection{Nudity}

Beyond Michael's feelings for Hanna and the romanticization of their relationship, their dynamic also entails a portrayal of Hanna's body and sexuality. Nudity proves to be a prominent theme in the film. This begs the question of how far Hanna's body is presented or even exploited through a Male Gaze.

Hanna is first seen naked standing behind Michael with a towel that she quickly drops [14:29]. The scene alternates between two shots: A medium shot behind Hanna, revealing her naked body in the right half of the image [14:25] and a medium shot that shows Hanna and Michael in the center of the shot [14:33]. Crucial in this scene is that Hanna presents herself, initiates and controls the situation so that the portrayal does not put her into a position of being a passive object. Instead, the autonomy of her sexuality is emphasized. Additionally, at this point, Hanna holds power over Michael and the situation. The scene does not reveal a classical Male Gaze shot, despite being narratively presented from Michael's point-of-view. Michael's observation of Hanna's body is not explicitly put in the foreground.

Throughout the relationship and the evolution of the situation in which Michael reads to Hanna, a particular camera shot, characteristic for the portrayal of Michael and Hanna's dynamic at this point in the film, is repeated. In this shot, Hanna's naked back can be seen in the bottom half of the image, while Michael occupies the center. Although the focus is on Michael's gaze, the camera does not adapt his perspective in the following shot in a traditional, anticipated point-of-view shot that would reveal what he is looking at. Hence, Hanna's naked body is shown but does not function as a means of sexual objectification. This is also realized through the central theme of the film-the act of Michael reading to Hanna, which uncovers Michael's privilege and intellectual advantage over Hanna.

Hanna's erotic impact on Michael and her sexual desire at the beginning of the film are at the center of her character development. Only at a later point in the narrative is her character expanded. Once Michael develops and clearly shows romantic feelings for Hanna, their sexual relationship fades into the background. This is particularly evident in the last scene of Hanna and Michael in the first time level of the narrative set in 1958 [41:32-42:06]. Here, we see Hanna and Michael in the center of a medium shot that moves into a close-up, mirroring their first sex scene [15:45-15:47]. Because these shots are paralleled, the difference between Hanna and Michael's emotional closeness, embodied by their tight embrace, is stressed. The emotionality and development of the relationship between Hanna and Michael are evident in this juxtaposition so that the motif of sexuality is eventually romanticized. This leaves open the question of how the analyzed function of sexuality, sexualization and romantic elements play into the portrayal of Hanna as a perpetrator.

\subsection{Hanna as a Perpetrator}

During the trial, Hanna's naiveté, uncertainty, and insecurity are exceedingly stressed, so that her criminal liability is, from the perspective of the viewer, questionable and, from the standpoint of the film, lessened. Crucial in this regard is Hanna's conviction that she did not have a choice. Assuming that legal culpability only occurs once the person in question is capable of an autonomous decision, the degree of Hanna's guilt and thus perpetration is, based on her statements during the trial, debatable 
and therefore also a point of conflict for the viewer (Von Wrochem 2013). Hanna's depiction as a perpetrator is clearly distinguished from an image of an explicitly cruel, demonized NS-beast. Instead, Hanna is characterized through her naiveté. She reacts to the judge's questions and allegations with utter incomprehension and consternation, repeatedly referencing the commands that were given to her and looking for protection and validation from the other guards [55:25-55:35; 01:08:44-01:08:50]. At the end of her first interrogation, Hanna shows that she does not understand why she is accused, obliviously asking "Should I never have signed up at Siemens?" [56:26].

That Hanna does not see the reprehensibility in the process of selection that occurred in the concentration camp she was supervising is discernible through her response to the judge's question, "To make room, you were picking out women and saying 'You, you and you have to be sent back to be killed'?" [56:00], asking him genuinely confused, "Well, what would you have done?" [56:11]. To Hanna, her actions were self-evident. It becomes clear that Hanna was not in the position to grasp the scope of her actions, and therefore her perpetration, at the time. Additionally, it is revealed that Hanna does not understand the political background of the situation and her former profession as a supervisor.

In Duesterberg's model of the three main strategies of the stereotyping of female NS-perpetrators, Hanna falls under the category of the naïve perpetrator incapable of an autonomous formation of will (Duesterberg 2002, p. 240). This is supported by the visual absence of her perpetration. Because the film takes up Michael's perspective and follows his knowledge, there are no flashbacks to Hanna's time as a supervisor or the night of the fire. Additionally, Hanna's role in the murders can be classified as passive. The trial distinctly reveals that Hanna did not display immense cruelty beyond her role as a supervisor, the consequences of which she did not see or understand. On the one hand, Hanna's perpetration and the degree of her guilt thus remain debatable, since her influence and the situation in which she made her choice are unclear to the viewer. On the other hand, the absence of portrayal of Hanna as a supervisor allows for a depiction of her perpetration that is free of any explicit cruelty or brutality.

Moreover, Hanna's naiveté and lack of cruelty becomes evident in her distinction from the other female perpetrators on trial. While the book of the survivor, Ilana Mather, is passed around in court, we see that one of the codefendants is knitting and declines to look at the book, remaining entirely uninterested [54:15-54:17]. A few seconds later, another shot reveals that one of the codefendants is also knitting, not paying attention to the trial [54:33]. The camera then shows a look shared between two of the codefendants while the judge's voice in the background can be heard, saying "so far, each of your fellow defendants has specifically denied being part of that process" [54:33-54:49]. The defendants' knowing smile and slight nod implies to the viewer that the former supervisors consciously lied to leave Hanna with the sole responsibility and thus guilt in hopes of avoiding a sentence themselves. When Hanna admits to being part of the selection process, we again see a triumphant smile from one of the other supervisors [54:57]. The viewer is thus directed to sympathize with Hanna. Hanna's emotional vulnerability and her visible insecurity are juxtaposed with her codefendants' indifference, although they appear to be aware of their liability [55:08-55:30]. Through this, Hanna's weakness is stressed and the viewers' condemnation and distancing from her character are decreased.

The same pattern is repeated when Hanna recalls the night of the fire. Shortly before that, Michael realizes that Hanna cannot read or write [01:09:26-01:09:42]. Hence, the viewer is aware of the fact that Hanna does not hold the sole responsibility or guilt and is wrongfully accused of writing the protocol by herself. Concerning this situation, Hanna takes up the role of a victim during the trial, diminishing her role as a perpetrator. Additionally, this exposes an ambiguity of perpetration as it reveals the ways in which Hanna is both a perpetrator and a victim.

Hanna does not take up the role of a Holocaust perpetrator until the second half of the film, at which point she has already been introduced and characterized through Michael's perspective. Hence, Hanna is not reduced to her role as a perpetrator, which supports the possibility for the viewer to empathize with her. During the scenes in the courthouse, which primarily make up the depiction of 
Hanna as a perpetrator, Hanna appears weak and helpless, a depiction that stands in stark opposition to her sexually confident, dominant, determined appearance during the beginning of her relationship with Michael. Consequently, there is a notable structural separation of Hanna as a sexual being, characterized through power; her persona as a lover, in which the power dynamic shifts to reveal her in a passive, dependent role; and her role as a perpetrator, straddling the horrors of her incomprehension with portrayals of her as a weak, isolated victim.

The structure of the film, consequently, reveals to be significantly influential to the perception and moral assessment of Hanna's perpetration. Moreover, the impact of Hanna's emphasized femininity with regards to her perpetration becomes clear. Her naiveté, lack of understanding and education, and her role as a victim that she thus assumes are characterized by the features that symbolize stereotypes of femininity. Hanna's naiveté concerning her perpetration thus stands in marked contrast to her initial role in relation to Michael, in which she reveals an aggressive, dominant side. Consequently, the relativization of Hanna's perpetration that, to a certain extent, denies her the complexity of a perpetrator and instead sharply limits her (moral) culpability, was preceded by a gradual shift from a morally questionable, highly dominant sexuality to a passive, helpless femininity. With that, Hanna's sexuality becomes a central part of the assessment of her perpetration.

\section{Conclusions}

Sexualization plays a notable role in many fictional depictions of female protagonists in Holocaust films (Wenk 2002). Displays of female perpetration break with a familiar structure of hyper-masculine perpetrators and feminized victims as well as rattle stereotypical notions of innocence and femininity (Friedrich 1994; Hirsch 2002). Consequently, scholars have noted a lack in complexity when it comes to the fictional depiction of female Holocaust perpetrators and instead noted a problematic sexual objectification (Brown 2011; Fuchs 1999; Magilow et al. 2012; Rapaport 2003). Among depictions of the overtly sexualized NS-beast, most poignantly portrayed in Nazisploitation cult films, stand narratives of female perpetrators characterized by a naiveté that ultimately decrement the perpetrator's culpability. This reflects the difficulty that depictions of female perpetrators in fictional Holocaust films seemingly implicate.

This paper has outlined how cinematic sexual objectification can play a significant role in the portrayal of female perpetration and, most notably, in the moral assessment of that perpetration. While NS-beasts, whose sexuality is unmistakably tied to their perpetration, are reduced to their sexualized bodies in a way that ultimately positions their deviant sexuality as the reason for their cruelness, the depiction of Hanna Schmitz in The Reader (Daldry 2008) marks a different conceptualization of female sexuality and perpetration. Hanna's sexuality does not find expression in her role as a perpetrator but is structurally separated from it. Instead, the reveal of Hanna's role as a perpetrator is, with a heterosexist lens, preceded by a distinct shift from her sexuality to her femininity. Only after the establishment of a romantic relationship is Hanna's perpetration revealed to the viewer and Michael, whose infatuated and ultimately pitying perspective presents Hanna to the viewer throughout the film.

The Reader does feature a sexualization in the sense of a classical Male Gaze. Although Michael's gaze on Hanna's body is shown, it is not followed by the second shot revealing the subject of this gaze. Moreover, as the film is largely told through Michael's perspective, the development of Hanna and Michael's affaire into a romantic relationship shifts the film's depiction of Hanna away from her being merely a (mysterious) erotic object. Despite the initially notable nudity and display of Hanna's body, she is ultimately not reduced to it.

Nevertheless, Hanna's sexuality plays a central role in her characterization and, consequently, the depiction and intradiegetic assessment of her role as a perpetrator. Hanna's sexuality is the gateway into a gradual feminization of her character which ultimately carries the diminishing of her perpetration. While the ambiguity of Hanna's perpetration is not completely resolved, the ways in which Hanna is a victim are more and more emphasized. The initially dichotomous motif of sexuality, which reveals Hanna's dominant, determined, and experienced side on the one hand and 
her weak, vulnerable and eventually entirely dependent side on the other hand, proves to be a means to emphasize Hanna's femininity. In the absence of a sexually objectifying Male Gaze, The Reader nevertheless uses its male narrative perspective to connect Hanna's sexuality to the portrayal of her as a perpetrator. Consequently, the arguably humanized portrayal of Hanna as a Holocaust perpetrator loses its potential to explore the complexity of perpetration as Hanna is, through a gradual feminization and in connection to her sexuality, ultimately exonerated from her responsibility. Further, The Reader ultimately reveals the limits of a popularized fictionalization of the Holocaust in exploring the intricacy of (female) perpetration.

Funding: This research received no funding.

Conflicts of Interest: The author declares no conflicts of interest.

\section{References}

\section{Primary Sources}

Angry Harvest. 1985. Directed by Agnieszka Holland. Germany: Central Cinema Company Film. Eichmann. 2007. Directed by Robert W. Young. United Kingdom: Regent Releasing.

Enemies, A Love Story. 1989. Directed by Paul Mazursky. USA: Morgan Creek Entertainment. Gold of Rome. 1960. Directed by Carlo LizzanI. Italy/France: Ager Cinematografica.

Ilsa, She Wolf of the SS. 1975. Directed by Don Edmonds. USA: Cambist Films.

Kapo. 1960. Directed by Gillo Pontecorvo. Italy/France: Cineriz.

La Bestia in Calore. 1977. Directed by Luigi Batzella. Italy: Eterna Film.

Life is Beautiful. 1997. Directed by Roberto Benigni. Italy: Cecchi Gori Group.

Playing for Time. 1980. Directed by Daniel Mann and Joseph Sargent. USA: CBS Television.

Schindler's List. 1993. Directed by Steven Spielberg. USA: Amblin Entertainment.

Triumph of the Spirit. 1989. Directed by Robert M. Young. USA: Nova International Films.

The Devil's Arithmetic. 2004. Directed by Donna Deitch. USA: Millbrook Farm Productions.

The Hiding Place. 1975. Directed by James F. Collier. USA: World Wide Pictures.

The Reader. 2008. Directed by Stephen Daldry, USA/Germany. Weinstein Company. Edition: DVD. SenatorHome Entertainment $\mathrm{GmbH}, 2009$.

\section{Secondary Sources}

Baron, Lawrence. 2010. The First Wave of American “Holocaust” Films, 1945-1959. The American Historical Review 115: 90-114. [CrossRef]

Brown, Adam. 2011. Screening Women's Complicity in the Holocaust: The Problems of Judgement and Representation. Holocaust Studies 17: 75-98. [CrossRef]

Connell, Robert W. 1987. Gender and Power: Society, the Person and Sexual Politics. Stanford: Stanford University Press. Donahue, William Collins. 2010. Holocaust as Fiction: Bernhard Schlink's 'Navi' Novels and Their Films. New York: Palgrave MacMillan.

Doneson, Judith E. 1987. The American History of Anne Frank's Diary. Holocaust and Genocide Studies 2: 149-60. [CrossRef]

Duesterberg, Julia. 2002. Von der 'Umkehr aller Weiblichkeit': Charakterbilder einer KZ-Aufseherin. In Gedächtnis und Geschlecht: Deutungsmuster des Nationalsozialistischen Genozids. Edited by Insa Eschbach, Sigrid Jacobeit and Silke Wenk. Frankfurt am Main: Campus Verlag, pp. 227-45.

Erens, Patricia, ed. 1990. Issues in Feminist Film Criticism. Bloomington: Indiana University Press.

Fredrickson, Barbara L., and Tomi-Ann Roberts. 1997. Objectification Theory: Toward Understanding Women's Lived Experiences and Mental Health Risks. Psychology of Women Quarterly 21: 173-206. [CrossRef]

Friedrich, Jörg. 1994. Die kalte Amnestie: NS-Täter in der Bundesrepublik. Frankfurt am Main: Piper.

Fuchs, Esther. 1999. Images of Women in Holocaust Films. Shofar: An Interdisciplinary Journal of Jewish Studies 17: 49-56. [CrossRef] 
Fuchs, Esther. 2008. Gender, Identity and Family in the European Holocaust Film: The Jewess as Virgin and Whore. In Life, Death and Sacrifice: Women and Family in the Holocaust. Edited by Esther Hertzog. Jerusalem and New York: Gefen Publishing House, pp. 287-305.

Haslam, Nick, Steve Loughnan, and Elise Holland. 2013. The Psychology of Humanness. In Objectification and (De)Humanization. Edited by Sarah J. Gervais. New York: Springer, vol. 60, pp. 25-51.

Heike, Irmtraud. 2008. Female Concentration Camp Guards as Perpetrators: Three Case Studies. In Ordinary People as Mass Murderers. Edited by Olaf Jensen and Claus-Christian W. Szejnmann. London: Palgrave Macmillan, pp. 120-39.

Heldman, Caroline, Laura Lazarus Frankel, and Jennifer Holmes. 2016. "Hot, Black Leather, Whip": The (De)evolution of Female Protagonists in Action Cinema, 1960-2014. Sexualization, Media, E Society 2: 1-19. [CrossRef]

Herkommer, Christina. 2008. Women under National Socialism: Women's Scope for Action and the Issue of Gender. In Ordinary People as Mass Murderers. Edited by Olaf Jensen and Claus-Christian W. Szejnmann. London: Palgrave Macmillan, pp. 99-119.

Hirsch, Marianne. 2002. Täter-Fotografien in der Kunst nach dem Holocaust: Geschlecht als Idiom der Erinnerung. In Gedächtnis und Geschlecht: Deutungsmuster des Nationalsozialistischen Genozids. Edited by Insa Eschbach, Sigrid Jacobeit and Silke Wenk. Frankfurt am Main: Campus Verlag, pp. 203-27.

Kuhn, Annette. 1985. The Power of the Image. New York: Routledge.

Langer, L. Lawrence. 1995. Admitting the Holocaust: Collected Essays. New York and Oxford: Oxford University Press.

LeMoncheck, Linda. 1985. Dehumanizing Women: Treating Persons as Sex Objects. Totowa: Rowman \& Littlefield Publishers.

Lewis, Ingrid. 2017. Women in European Holocaust Films: Perpetrators, Victims and Resisters. Cham: Springer International Publishing.

MacKinnon, Catharine. 1987. Feminism Unmodified: Discourses on Life and Law. Cambridge: Harvard University Press.

Magilow, Daniel H., Elizabeth Bridges, and Kristin T. Vander Lugt, eds. 2012. Nazisploitation! The Nazi Image in Low-Brow Cinema and Culture. New York: Continuum.

Metz, Joseph. 2004. "Truth Is a Woman": Post-Holocaust Narrative, Postmodernism, and the Gender of Fascism in Bernhard Schlink's “Der Vorleser”. The German Quarterly 77: 300-23.

Mulvey, Laura. 1985. Visual Pleasure and Narrative Cinema. In Film Theory and Criticism: Introductory Readings, 3rd ed. Edited by Gerald Mast and Marshall Cohen. New York: Oxford University Press, pp. 803-16.

Mushaben, Joyce Marie. 2004. Memory and the Holocaust: Processing the Past through a Gendered Lens. History of the Human Sciences 17: 147-85. [CrossRef]

Nickel, Claudia, and Silke Segler-Meßner, eds. 2013. Von Tätern und Opfern: Zur medialen Darstellung politisch und ethnisch motivierter Gewalt im 20./21. Jahrhundert. Frankfurt am Main: Peter Lang.

Nussbaum, Martha C. 1995. Objectification. Philosophy \& Public Affairs 24: 249-91. [CrossRef]

Rapaport, Lyn. 2003. Holocaust Pornography: Profaning the Sacred in Ilsa, She-Wolf of the SS. Shofar: An Interdisciplinary Journal of Jewish Studies 22: 53-79. [CrossRef]

Reading, Anna. 2002. The Social Inheritance of the Holocaust: Gender, Culture and Memory. New York: Palgrave MacMillan.

Reemtsma, Jan Phillip. 2007. Flucht und Vertreibung bei Arno Schmidt und Walter Kempowski. In Täter als Opfer? Deutschsprachige Literatur zu Krieg und Vertreibung im 20. Jahrhundert. Edited by Stefan Hermes and Amir Muhic. Hamburg: Kovač, pp. 57-74.

Relke, Diana. 2011. The Goyish Gaze: Reading against American Movie Review of The Reader. Canadian Review of American Studies 41: 370-94. [CrossRef]

Sander, Daniel. 2009. Holocaust-Drama The Reader: Schuld und Sünde. February 26. Available online: https: //www.spiegel.de/kultur/kino/holocaust-drama-der-vorleser-schuld-und-suende-a-609882.html (accessed on 25 August 2019).

Sarti, Wendy Adele-Marie. 2011. Women as Nazis: Female perpetrators of the Holocaust. Palo Alto: Academica Press. Schlipphacke, Heidi M. 2002. Enlightenment, Reading, and the Female Body: Bernhard Schlink's Der Vorleser. Gegenwartsliteratur 1: 310-28.

Schulz-Ojala, Jan. 2009. Die Unmoral der Liebe. February 26. Available online: http://www.tagesspiegel.de/kultur/ kino/schlink-verfilmung-der-vorleser-die-unmoral-der-liebe/1459800.html (accessed on 25 August 2019). 
Shipman, Tim. 2009. Kate Winslet's Oscar Chances Hit by The Reader Nazi Accusation. February 15. Available online: http://www.telegraph.co.uk/culture/film/oscars/4624573/Kate-Winslets-Oscar-chances-hit-by-TheReader-Nazi-accusation.html (accessed on 25 August 2019).

Sjoberg, Laura. 2013. Gendering Global Conflict: Toward a Feminist Theory of War. New York: Columbia University Press. Stiglegger, Marcus. 1999. Sadiconazista: Faschismus und Sexualität im Film. St. Augustin: Gardez! Verlag.

Szymanski, Dawn M., Lauren B. Moffitt, and Erika R. Carr. 2011. Sexual Objectification of Women: Advances to Theory and Research. The Counseling Psychologist 39: 6-38. [CrossRef]

Vandermassen, Griet. 2010. Woman as Erotic Object in Mainstream Cinema: A Darwinian Inquiry into the Male Gaze. Evolutionary Review 1: 69-75.

Von Wrochem, Oliver. 2013. Zur Auseinandersetzung mit NS-Verbrechen: Perspektiven von Tätern und Opfern und deren Nachkommen. In Von Tätern und Opfern: Zur medialen Darstellung politisch und ethnisch motivierter Gewalt im 20./21. Jahrhundert. Edited by Claudia Nickel and Silke Segler-Meßner. Frankfurt am Main: Peter Lang, pp. 61-78.

Waterhouse-Watson, Deb, and Adam Brown. 2014. Between Whores and Heroes: Women, Voyeurism and Ambiguity in Holocaust Film. Outskirts 30. Available online: http://www.outskirts.arts.uwa.edu.au/volumes/ volume-30/waterhouse-watson-and-brown (accessed on 25 August 2019).

Waterhouse-Watson, Deb, and Adam Brown. 2016. Mothers, Monsters, Heroes and Whores: Reinscribing Patriarchy in European Holocaust Films. Dapim: Studies on the Holocaust 30: 142-57. [CrossRef]

Wenk, Silke. 2002. Rhetoriken der Pornografisierung: Rahmungen des Blicks auf die NS-Verbrechen. In Gedächtnis und Geschlecht: Deutungsmuster des Nationalsozialistischen Genozids. Edited by Insa Eschbach, Sigrid Jacobeit and Silke Wenk. Frankfurt am Main: Campus Verlag, pp. 269-94.

Zurbriggen, Eileen L., Rebecca L. Collins, Sharon Lamb, Tomi-Ann Roberts, Deborah L. Tolman, Monique Ward, and Jeanne Blake. 2007. Report of the APA Task Force on the Sexualization of Girls. Available online: http://www.apa.org/pi/women/programs/girls/report-full.pdf (accessed on 25 August 2019).

(C) 2019 by the author. Licensee MDPI, Basel, Switzerland. This article is an open access article distributed under the terms and conditions of the Creative Commons Attribution (CC BY) license (http://creativecommons.org/licenses/by/4.0/). 